\title{
TEKNIK MENGHITUNG FEKUNDITAS TELUR IKAN LAIS (Criptopterus sp.) DI SUAKA PERIKANAN SUNGAI SAMBUJUR DAERAH ALIRAN SUNGAI BARITO, KALIMANTAN SELATAN
}

\author{
Burnawi \\ Teknisi Litkayasa pada Balai Riset Perikanan Perairan Umum, Mariana-Palembang \\ Teregristasi I tanggal: 23 Desember 2005; Diterima setelah perbaikan tanggal: 10 Mei 2006; \\ Disetujui terbit tanggal: 27 Maret 2007
}

\section{PENDAHULUAN}

Sungai Barito adalah sungai yang terpanjang di Indonesia berada pulau Kalimantan, bagian hulu berada di Serawak Negara Malaysia sedangkan bagian hilir Sungai Barito terletak di Propinsi Kalimantan Selatan dan Sungai Barito ini langsung bermuara ke Laut Jawa.

Sungai Sambujur adalah anak Sungai Barito yang terletak di perairan daerah aliran Sungai Barito bagian selatan. Daerah ini adalah rawa banjiran dan rawa lebak yang dipengaruhi oleh pasang surut dan di sekitar banyak ditumbuhi oleh tegakkan tanaman. Salah satu Suaka Perikanan yang berfungsi berada di Sungai Sambujur daerah aliran Sungai Barito Kalimantan Selatan (Prasetyo, 2005).

Ikan lais (Criptopterus sp.) merupakan jenis ikan ekonomis penting yang hidup dan berkembang biak secara alami di perairan umum terutama tipe hutan rawa, sungai mati yang sesuai tempat kehidupan ikan lais, daerah tersebut sebagai tempat spawning grount, serta nursery ground ikan (Utomo et al., 1999).

Studi aspek biologi ikan tentang fekunditas berguna untuk mengetahui jumlah telur ikan, maka dari itu studi fekunditas telur ikan lais untuk menunjang dan mendukung kajian populasi ikan dalam pengelolaan perikanan di perairan di Suaka Perikanan Sungai Sambujur daerah aliran Sungai Barito, Kalimantan Selatan.

Adapun tujuan penulisan makalah ini adalah untuk menguraikan teknik pemeriksaan telur dan untuk mengetahui informasi fekunditas telur ikan lais yang sangat berguna untuk mendukung pengelolaan perikanan di suaka perikanan Sungai Sambujur daerah aliran Sungai Barito Kabupaten Hulu Sungai Utara, Kalimantan Selatan.

\section{BAHAN DAN METODE}

Teknik menghitung fekunditas telur ikan lais di suaka perikanan Sungai Sambujur daerah aliran
Sungai Barito, Kalimantan Selatan ada beberapa bahan dan metode yakni mempersiapkan bahan, alat, dan prosedur kerja:

1. Bahan: 1) air; 2) larutan Gilson; 3) gonad ikan lais; 4) kertas kalkir.

2. Alat: 1) dessecting set; 2) petridish; 3) mikroskop; 4) baskom 5) ember; 6 dan 7) kotak plastik (cool box); 8) pensil 2B; 9) papan ukur; 10) talenan; 11) botol; 12) contoh; 13) kertas saring; 14) counter; 15) timbangan dengan ketelitian $0,01 \mathrm{~g}$.

\section{Prosedur Kerja}

Teknik menghitung fekunditas telur ikan lais memakai metode gravimetri yang dikatakan oleh Efendi (2002). Cara memeriksa fekunditas telur ikan lais ada beberapa tahapan:

\section{Pengawetan gonad}

a. Ikan lais ditimbang memakai alat timbangan dengan ketelitian $0,1 \mathrm{~g}$, diukur panjang dengan memakai papan ukur semua data ini dicatat dalam tabulasi data.

b. Ikan lais diletakkan di atas talenan, kemudian dibedah bagian perut mulai dari pangkal sirip dada sampai dengan ke lubang anus. Pembedahan ini dilakukan memakai gunting dan pisau bedah, ketika membedah perut ikan tersebut harus dilakukan secara hati-hati supaya tidak melukai gonad ikan sehingga telur tidak keluar dari kantong telur.

c. Pemotongan gonad ikan mulai dari bagian pangkal gonad lalu ditimbang menggunakan timbangan yang memiliki ketelitian $0,01 \mathrm{~g}$ data penimbangan dicatat dalam buku data lapangan dan kemudian dimasukkan ke dalam botol contoh dan diberi larutan gilson $10 \%$, sampai dengan seluruh gonad ikan terendam dalam cairan gilson tersebut.

d. Di dalam botol contoh dimasukkan catatan dari kertas kalkir ditulis memakai pensil 2B catatan tersebut antara lain berisi nomor atau kode, nama ikan, ukuran panjang, ukuran bobot, bobot gonad, lokasi, dan tanggal pengambilan contoh, kemudian botol contoh tersebut disimpan dalam box plastik. 
2. Cara memilah dan menghitung telur

a. Gonad ikan dikeluarkan dari dalam botol contoh, lalu dimasukkan ke dalam petridish untuk dilakukan pencucian dengan air dibilas 3 kali sampai dengan bau gilson hilang.

b. Gonad diletakkan di atas kertas saring, yang diletakkan di atas petridish dan dibiarkan atau dikeringanginkan selama \pm 10 menit.

c. Setelah pengeringan telur selesai, gonad ditimbang untuk mengetahui bobot gonad ikan atau ekor.

d. Untuk mengetahui fekunditas mutlak, gonad dipotong menjadi 3 bagian yakni pangkal, tengah, ujung, dan masing-masing bagian tersebut diambil $3 \%$ dari bobot bagian tersebut dan dimasukkan dalam petridish. e. Kemudian setiap telur ikan dipisahkan dari selaput telur dan kantong-kantong telur memakai pinset dan dihitung memakai alat counter, setelah diketahui jumlah telur pada masing-masing bagian gonad, jumlah telur dihitung berdasarkan pada persentase yang dikalikan dengan jumlah bobot total telur dan data tersebut dicatat dalam data tabulasi.

\section{Hasil Pengamatan}

Gonad ikan lais yang diperiksa di laboratorium didapatkan dari hasil tangkapan nelayan di Suaka Perikanan Sungai Sambujur daerah aliran Sungai Barito, Kalimantan Selatan. Dari hasil pengamatan ikan lais dengan kisaran bobot ikan 10 sampai dengan $40 \mathrm{~g}$, kisaran bobot gonad antara 0,1 sampai dengan $2,73 \mathrm{~g}$, fekunditas antara 197 sampai dengan 5.146 butir (lihat Tabel 1).

Tabel 1. Kisaran bobot ikan, bobot gonad, dan fekunditas lais yang didapat selama pengambilan contoh, tahun 2004

\begin{tabular}{cccc}
\hline Jenis Ikan & $\begin{array}{c}\text { Kisaran bobot ikan } \\
(\mathbf{g})\end{array}$ & $\begin{array}{c}\text { Kisaran bobot gonad } \\
(\mathbf{g})\end{array}$ & $\begin{array}{c}\text { Kisaran fekunditas } \\
(\mathbf{b t r})\end{array}$ \\
\hline Lais $(47$ ekor) & $17,5-40$ & $0,1-2,73$ & $197-5146$ \\
\hline
\end{tabular}

Sumber: Prasetyo, D., 2005

\section{KESIMPULAN}

Fekunditas ikan lais hasil tangkapan di Suaka Perikanann daerah aliran Sungai Barito dengan bobot ikan $40 \mathrm{~g}$ dan memiliki bobot gonad 2,73 $\mathrm{g}$ dengan jumlah telur 5.146 butir.

\section{DAFTAR PUSTAKA}

Effendi, M. I. 2002. Metode biologi perikanan. Bagian Ichtiologi. Fakultas Perikanan Institut Pertanian Bogor. Bogor. 110 hal.

Utomo, A. D. \& Asyari. 1999. Peranan ekosistem hutan rawa air tawar bagi kelestarian sumber daya perikanan di Sungai Kapuas, Kalimantan Barat. Jurnal Penelitian Perikanan Indonesia. Vol.V.
No.3. Pusat Penelitian dan Pengembangan Perikanan. Badan Penelitian dan Pengembangan Pertanian. Jakarta. 1-14.

Prasetyo, D. 2005. Kebiasaan makan dan musim pemijahan ikan lais (Criptopterus sp.) di suaka perikanan Sangai Sambujur Kabupaten Hulu sungai utara Kalimantan Selatan. Jurnal Perikanan Universitas Gajah Mada. Yogyakarta. Vol. VII No.2. Hal. 121-127.

\section{UCAPAN TERIMA KASIH}

Penulis menghaturkan ucapan terima kasih sebesar-besarnya pada Bapak Drs. Dadiek Prasetyo yang telah memberi saran dan koreksinya, dan dewan redaksi serta pengetik naskah sehingga terlaksananya tulisan ini. 
Lampiran 1.

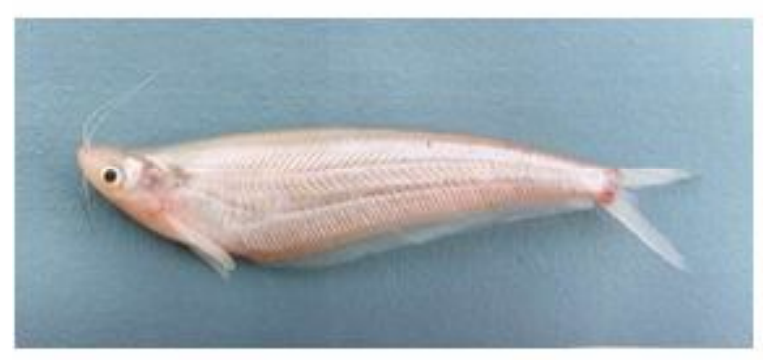

Gambar 1. Ikan lais.

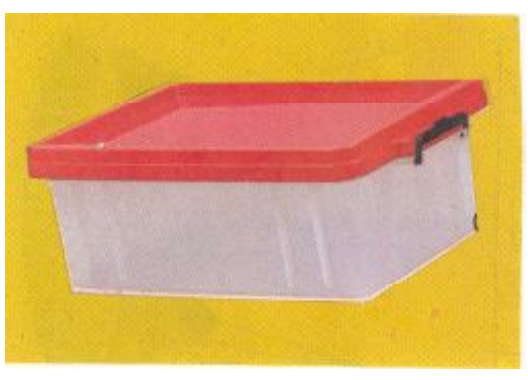

Gambar 2. Box Plastik.

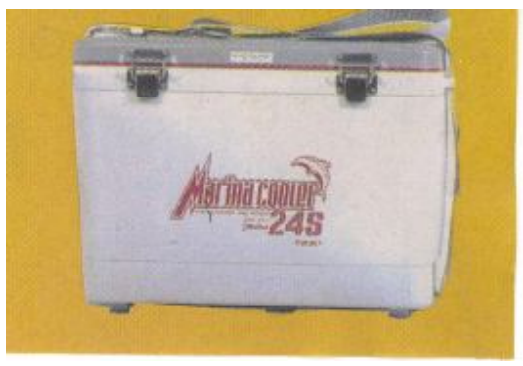

Gambar 3. Cool Box.

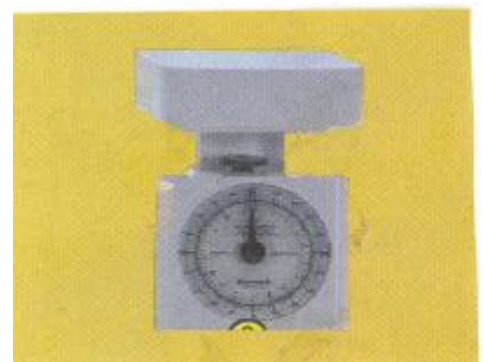

Gambar 4. Timbangan.

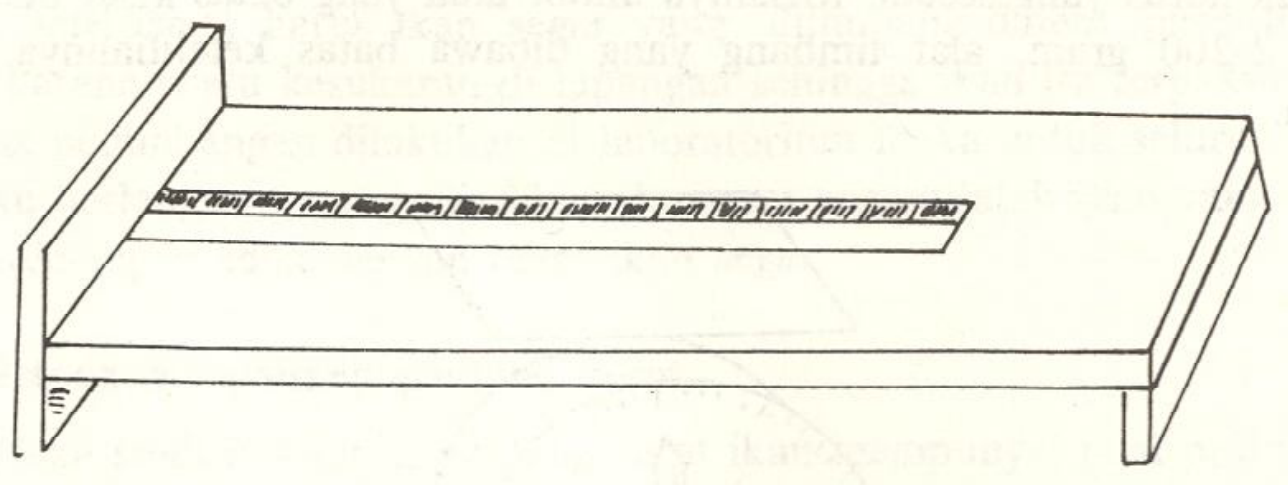

Gambar 5. Papan Ukur. 
Lampiran 2. Peta lokasi penelitian suaka Sungai Sambujur Kabupaten Hulu Sungai Utara Kalimantan Selatan

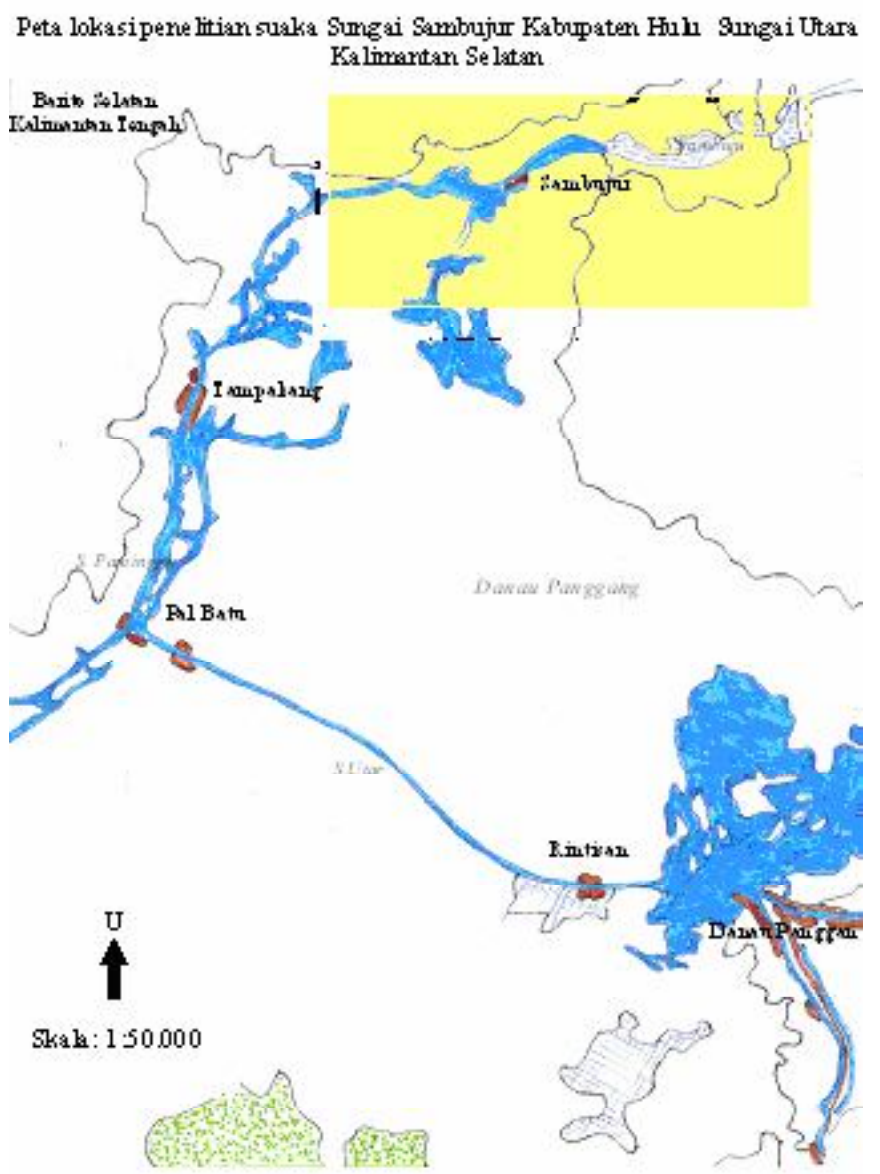

